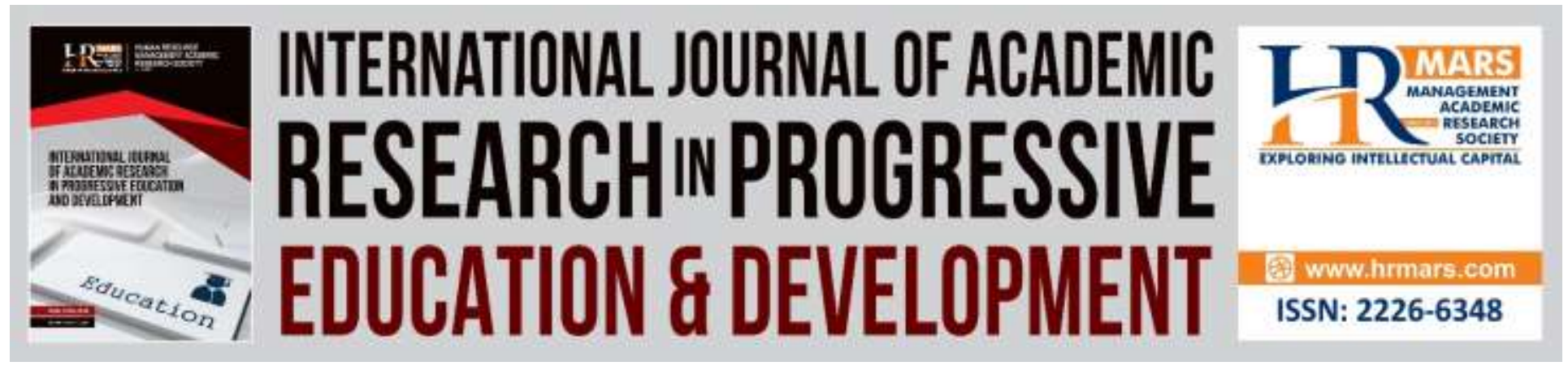

\title{
Identifying Language Learning Strategies Used by ESL Learners in A Rural Primary School
}

Patrick Duffy Bayuong, Harwati Hashim, Melor Md. Yunus

To Link this Article: http://dx.doi.org/10.6007/IJARPED/v8-i3/6311

DOI: $10.6007 /$ IJARPED/v8-i3/6311

Received: 19 July 2019, Revised: 09 August 2019, Accepted: 02 September 2019

Published Online: 23 September 2019

In-Text Citation: (Bayuong, Hashim, Yunus, 2019)

To Cite this Article: Bayuong, P. D., Hashim, H., Yunus, M. M. (2019). Identifying Language Learning Strategies Used by ESL Learners in A Rural Primary School. International Journal of Academic Research in Progressive Education and Development. 8(3), 151-165

Copyright: (C) 2019 The Author(s)

Published by Human Resource Management Academic Research Society (www.hrmars.com)

This article is published under the Creative Commons Attribution (CC BY 4.0) license. Anyone may reproduce, distribute, translate and create derivative works of this article (for both commercial and non-commercial purposes), subject to full attribution to the original publication and authors. The full terms of this license may be seen

at: http://creativecommons.org/licences/by/4.0/legalcode

\section{Vol. 8(3) 2019, Pg. 151 - 165}

http://hrmars.com/index.php/pages/detail/IJARPED

JOURNAL HOMEPAGE

Full Terms \& Conditions of access and use can be found at http://hrmars.com/index.php/pages/detail/publication-ethics 


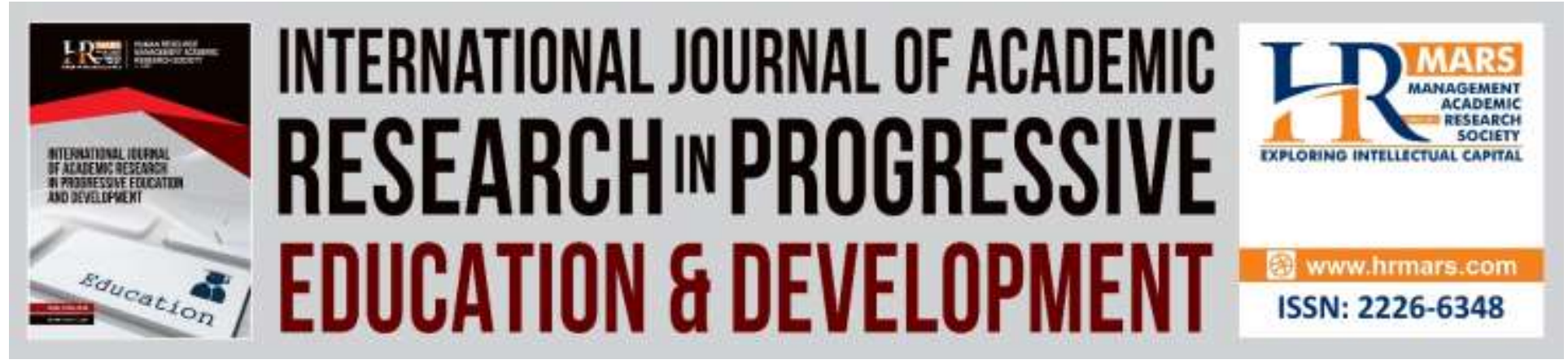

\title{
Identifying Language Learning Strategies Used by ESL Learners in A Rural Primary School
}

\author{
${ }^{1 *}$ Patrick Duffy Bayuong, ${ }^{2}$ Harwati Hashim, ${ }^{2}$ Melor Md. Yunus \\ ${ }^{1}$ Sekolah Kebangsaan Pusa, D/A Pejabat Pendidikan Daerah Betong, 94950 Pusa, Sarawak, \\ Malaysia, ${ }^{2}$ Faculty of Education, Universiti Kebangsaan Malaysia, 43600 Bangi, Selangor, \\ Malaysia \\ Email: anothaikenzat@yahoo.com.my
}

\begin{abstract}
Language Learning Strategies (LLSs) are crucial and helpful in the learning of English as a second language (ESL). However, it appeared that the unawareness of their LLSs has affected ESL learners in the area of this study in their learning of English language. Therefore, this study was conducted to identify the LLSs used among ESL learners in a rural primary school. Data were collected using a survey research design through questionnaire. A set of questionnaire comprises four parts were given to a group of 30 Year 6 pupils in a rural area primary school in Borneo, Malaysia. Data collected showed that majority of or almost all respondents used the listening strategies listed in the questionnaire. Meanwhile, only limited speaking strategies being used by respondents in this study. This is because there was a big number of respondents who felt that speaking strategies are not significant to them due to limited usage of English language. These findings illuminated that majority of the respondents did not use some speaking strategies listed in the questionnaire when learning the English language. For translation strategies, data collected showed that the respondents used the translation strategies listed in the questionnaire when learning the English language. The findings of this study benefit the language teachers in primary schools in a way that these findings appear to be a good reference for them to be aware of their teaching approaches and to ensure their approaches suit learners' LLSs. Overall, the findings of this study showed that listening and translation strategy supported learners more in their language learning.
\end{abstract}

Keywords: English as a Second Language (ESL), ESL Learners, Language Learning Strategies (LLSs), Rural Area Primary School, Year 6 Pupils

\section{Introduction}

A good language learner possesses different characteristics than the others in order to learn a new language. He uses various learning strategies including cognitive and metacognitive strategies (Oxford \& Nyikos, 1989). Apart from that, a good language learner is more motivated, 
aware of his own learning styles, does not worry about making mistakes and confidents in his capability to learn a new language (Thompson, 2005). A previous study reported that motivation appeared to be the most significant factor on the use of Language Learning Strategies (LLSs) among the learners (Tamada, 1996; Rahimi, Riazi \& Saif, 2004). Oxford (2003a) shared the similar thought in which he referred motivation in language learning as a desire to learn another language and this motivation causes an individual to do something or act in a certain way. Meanwhile, Kajan and Shah (2019) came up with a statement that motivation and attitude are two important features that must link together and every language learner needs to have them to ensure their learning of second language a success. In the learning process of English as Second Language (ESL), a language learner needs to have good LLSs as these strategies direct the learning process of the language learner. LLSs has been a topic of discussion in various researches for their importance to language learners on their language learning process. LLSs also benefit language learners in various ways. LLSs mould the language learners to become autonomous in which they learn on their own (Benson \& Voller, 1997), alert of their roles (Surma, 2004), and are responsible for their own learning (Holec, 1981, as cited in Surma, 2004). LLSs also benefit language learners in such a way that they assist learners in improving their knowledge and understanding of a target language (Cohen, 1995; Cohen, 2001) or a new language they are learning now. In learning of ESL, a good language learner is believed to include the knowledge of his or her first language in the learning of a second language (Rubin, 1975; Stern, 1975; Rubin and Thompson, 1994; as cited in Zare, 2012). Oxford (2003b) asserted that LLSs help determine how and how well the language learners learn a second or foreign language. Since the English language is made as a compulsory subject in all Malaysian primary schools, it therefore functions as one of the mediums of instructions in classroom settings where, as noted by Oxford (2003b) a lot of inputs exist in this second language. In the learning process of the English language as a target language in both communicative and writing, a language learner needs to acquire the language skills which are listening, speaking, reading, and writing skill. Grammar and vocabulary are also taken into account. Each language skill has its own strategies that address how and how good a language learner learns the English language, and to what extend does a language learner has applied these strategies in the language learning process.

Therefore, this study serves as a platform to identify the language learning strategies used among ESL learners at a primary school in a rural area in Bornoe, Malaysia. Translation strategies are taken into consideration as based on the adopted questionnaire on Young Learner's Language Strategy Use Survey by Cohen and Oxford (2002) as cited in Cohen and Weaver (2005). Specifically, this study intends to answer the following questions:

1) To what extent do the ESL learners use listening strategies in their language learning process?

2) To what extent do the ESL learners use speaking strategies in their language learning process?

3) To what extent do the ESL learners use translation strategies in their language learning process? 
DEVELOPMENT

Vol. 8, No. 3, 2019, E-ISSN: 2226-6348@ 2019 HRMARS

\section{Literature Review \\ Language learning strategies (LLSs)}

Learning strategies can be regarded as steps taken by an individual in his learning process of something. Learning strategies, according to Mayer (1988) as cited in Gu (2005) refer to the intended behaviours of a learner which play the important roles to influence how the learner processes information. Above all nine selected definitions of learning strategies taken from some professional experts in the area of language learning, Gu came up with his own definition in which he defined LS as "something used by students to accomplish learning" (Gu, 2005). Zare (2012) stated that learning strategies benefit a language learner through their contribution to the development of the language system created by him or her. With regard to second language learning, Cohen (1995) defined "strategies" as general approaches and specific actions or techniques used to learn a second language.

Cohen (2002) defined LLSs as the strategies to identify the materials that need to be learned. In line with LLSs, Macaro (2004) pinpointed that some strategies desired essential level of linguistic knowledge in order to be utilized. LLSs may also be regarded as steps which include mental activities taken by the students or language learners to learn a new language. In addition to this, LLSs function as a platform for language learners to develop their understanding as they move towards language proficiency (Oxford \& Nyikos, 1989). Through mental activities, the language learners will be able to understand fully the new information regarding the new language that they learn before assimilating them into their existing knowledge. Oxford and Nyikos (1989) categorized this learning strategy as cognitive strategies which the learners associate new information with the existing information in long-term memory.

\section{Listening Strategies}

Listening is a vital part of all learning (Chitravelu, Sithamparam \& Choon, 2005), and it is a challenging skill to teach (Chitravelu, Sithamparam \& Choon, 2005; Celce-Murcia, Brinton \& Snow, 2014), because a teacher needs to ensure the learners are always motivated to learn (Chitravelu, Sithamparam \& Choon, 2005). Celce-Murcia, Brinton and Snow (2014) identified two challenges with listening that the learners and teachers are facing with: 1) lack of understanding of what listening entails; and 2) how comprehension is achieved. Listening is an active skill as it require learners to really pay attention to what they are listening to in order to gain understanding. In LLSs, listening strategies refer to specific methods or techniques the language learners use to learn a new language through listening.

\section{Speaking Strategies}

Pinter (2006) as cited in Shin and Crandall (2014) pointed out that an individual has to speak and think at the same time for him to be able to speak fluently. This explained why speaking is considered as a challenging process that demands both speaking and learning and speaking at the same time. As a part of language skills, speaking is the essence of communication because most speaking is one part of a two-ways conversation (Shin and Crandall, 2014). Through speaking, the speakers (in the context of this study language learners) can communicate or convey information to others. In addition, they are able to express themselves and their thoughts 
Vol. 8, No. 3, 2019, E-ISSN: 2226-6348 C 2019 HRMARS

through speaking. Appropriate speaking strategies are crucial to ensure the productivity of the communication or what is intended to say.

\section{Translation Strategies}

In the context of this study, translation strategies are applied when a language learner translates the English language into his mother tongue (L1) which is Bahasa Melayu (Malay) in order for him to understand the content delivered. Translation strategies function well if the sentence in the target language (in the context of this study English) has the similar structure with its translation in learner's mother tongue (L1) but it does not function well if the sentence structure is different in each language. With regard to Subject-verb agreement (SVA), students of L2 (English) in Malaysia have problems in SVA due to the reason that their L1 (Malay) does not have rules regarding SVA (Surina and Kamaruzaman, 2009; Siti \& Mohd, 2010) and this explains why most of them have problems in their writing (Siti \& Mohd, 2010). It is same goes to other language skills too.

Somehow, translation strategies do have benefits to the language learners. In one study by Abdul and Hafiza (2016), it was noted that the lecture gives a mental inconvenience to the learners if only the target language is used in the lecture because there would be lack of understanding. In further details, $98 \%$ of the respondents agreed that reading translation enhances understanding of the text; $80 \%$ agreed that the translation of texts keeps the learners' interest in the lecture; and $76 \%$ agreed that the translation in the national language helps building vocabulary in an easy way (Abdul \& Hafiza, 2016).

\section{Methodology}

This study was conducted using a survey research design through questionnaires adopted from Young Learner's Language Strategy Use Survey by Cohen and Oxford (2002) as cited in Cohen and Weaver (2005). The survey method was employed in this study because it is the appropriate method of collecting data to serve the aim of the study. A set of questionnaires consists of four parts, namely Part A, B, C and D was administered to a group of purposive sampling comprises 30 Year 6 pupils in a rural primary school in Borneo, Malaysia. Part A is meant to collect information on demographic profiles of the respondents. Respectively, Part $B, C$ and $D$ is meant to collect data on respondents' listening strategies use, speaking strategies use, and translation strategies use in their language learning process. Part B, C and D, respectively adopted the threepoint Likert scale (1: The statement isn't like you, 2: The statement is somewhat like you, 3: The statement really describes you). Part A, B, C and D, respectively consists of 3, 18, 13 and 5 items which make up to a total of 39 items. Data from this study were analysed using Statistical Package for the Social Sciences (SPSS).

\section{Results/ Discussion}

Table I shows the demographic profiles of the respondents. The respondents are Primary 6 pupils and they are currently studying in a rural primary school. All of them are Malays and their mother tongue (L1) is Bahasa Melayu (Malay language). 
Vol. 8, No. 3, 2019, E-ISSN: 2226-6348 @ 2019 HRMARS

Table 1: Demographic profiles of the respondents

\begin{tabular}{|c|c|c|c|}
\hline No. & \multicolumn{2}{|c|}{ Item } & \% \\
\hline 1 & \multirow{2}{*}{ Gender } & Male & $14(46.7)$ \\
\cline { 3 - 4 } & & Female & $16(53.3)$ \\
\hline 2 & Primary & Six & $30(100)$ \\
\hline 3 & Race & Malay & $30(100)$ \\
\hline
\end{tabular}

RQ 1: To what extent do the ESL learners use listening strategies in their language learning process?

Findings in Table 2 are to answer the first research question. Table 2 shows the findings on listening strategies used by the respondents. As shown in Table 2 (Section 1), strategy "I watch TV shows in the language" denoted the highest mean score (2.43), and percentage of respondents $(56.7 \%)$ and $(43.3 \%)$ who thought this statement is somewhat like them and really describes them, respectively. It was probably because every house has got at least a television. Therefore, the respondents watched TV shows in the English language in order to listen more to this language. Meanwhile, only one respondent (3.3\%) did not listen to people speaking the language in order to listen more to the English language. This implied that 29 respondents $(96.7 \%)$ listened to people speaking the language in order to listen more to the English language. The findings in Table 2 also showed that strategy "I listen to the radio in the language" has the lowest mean score (1.63). This is probably due to the reason that not all respondents have got the radios at home or they did not find listening to the radio is one of the strategies to listen more to the English language. Furthermore, the emergence of Information and Communication Technology (ICT) such as social media (SM) has provided them with various rooms to explore more about the English language.

Findings in Table 2 (Section 2) also revealed that 29 respondents (96.7\%) asked the person to speak the new sound in order to understand sounds and this strategy denoted the highest mean score (2.70). The findings also illuminated that only one respondent (3.3\%) who did not use each of these three strategies (I try to remember unfamiliar sounds I hear; I ask the person to speak the new sound; and I listen to the rise and fall of sounds) in order to understand sounds in the English language. Strategy "I find sounds in the language that are like sounds in English" denoted the lowest mean score in this section but there were 25 respondents (83.3\%) used this strategy in order to understand sounds in the English language. It was revealed that majority of the respondents used all four listening strategies listed in this Section 2 based on the mean scores 2.00 and above.

As Table 2 shows, strategy "I listen for the important words" denoted the second highest mean score (2.27) in Section 3 with the least number of respondent (6.7\%) who did not use this listening strategy. This revealed that almost all respondents (93.3\%) have used this listening strategy in order to understand what they hear. Strategy "I listen to words that are repeated" came up with the highest mean score (2.50) because a total of 20 respondents $(66.7 \%)$ which is 10 respondents more than number of respondents in the strategy "I listen for the important words" who thought this strategy really describes them. Listening strategies mentioned in Section 3 signify important 
Vol. 8, No. 3, 2019, E-ISSN: 2226-6348@ 2019 HRMARS

thing that a teacher should be aware of when teaching listening to the language learners in the classroom which is to make sure the learners understand what he is saying. Chitravelu, Sithamparam and Choon (2005) addressed that a pupil is completely hindered or held back in his learning if he cannot understand what the teacher is saying in the classroom. They further mentioned the aim of listening component which is to develop learners' ability to listen to information with understanding and precision.

Table 2: Distribution, frequency and mean on listening strategies use

\begin{tabular}{|c|c|c|c|c|c|}
\hline No. & Item & $\begin{array}{c}\text { The } \\
\text { statement } \\
\text { isn't like you } \\
\text { (\%) }\end{array}$ & $\begin{array}{c}\text { The } \\
\text { statement is } \\
\text { somewhat } \\
\text { like you (\%) }\end{array}$ & $\begin{array}{c}\text { The } \\
\text { statement } \\
\text { really } \\
\text { describes } \\
\text { you (\%) }\end{array}$ & Mean \\
\hline $\begin{array}{c}\text { Section } \\
1\end{array}$ & What I do to listen more: & & & & \\
\hline 1 & $\begin{array}{l}\text { I listen to the radio in the } \\
\text { language. }\end{array}$ & $14(46.7)$ & $13(43.3)$ & $3(10.0)$ & 1.63 \\
\hline 2 & $\begin{array}{l}\text { I watch TV shows in the } \\
\text { language. }\end{array}$ & 0 & $17(56.7)$ & $13(43.3)$ & 2.43 \\
\hline 3 & $\begin{array}{l}\text { I go to movies that use the } \\
\text { language. }\end{array}$ & $8(26.7)$ & $14(46.7)$ & $8(26.7)$ & 2.00 \\
\hline 4 & $\begin{array}{l}\text { I listen to the language if I } \\
\text { am in a restaurant or see } \\
\text { movies in the language. }\end{array}$ & $10(33.3)$ & $15(50.0)$ & $5(16.7)$ & 1.83 \\
\hline 5 & $\begin{array}{l}\text { If I hear people speaking } \\
\text { the language, I listen. }\end{array}$ & $1(3.3)$ & $21(70.0)$ & $8(26.7)$ & 2.23 \\
\hline $\begin{array}{c}\text { Section } \\
2\end{array}$ & $\begin{array}{l}\text { What I do to understand } \\
\text { sounds: }\end{array}$ & & & & \\
\hline 6 & $\begin{array}{l}\text { find sounds in the } \\
\text { language that are like } \\
\text { sounds in English. }\end{array}$ & $5(16.7)$ & $15(50.0)$ & $10(33.3)$ & 2.17 \\
\hline 7 & $\begin{array}{l}\text { I try to remember } \\
\text { unfamiliar sounds I hear. }\end{array}$ & $1(3.3)$ & $9(30.0)$ & $20(66.7)$ & 2.63 \\
\hline 8 & $\begin{array}{l}\text { I ask the person to speak } \\
\text { the new sound. }\end{array}$ & $1(3.3)$ & $7(23.3)$ & $22(73.3)$ & 2.70 \\
\hline 9 & $\begin{array}{l}\text { I listen to the rise and fall } \\
\text { of sounds (the music of } \\
\text { the language). }\end{array}$ & $1(3.3)$ & $15(50.0)$ & $14(46.7)$ & 2.43 \\
\hline $\begin{array}{c}\text { Section } \\
3 \\
\end{array}$ & $\begin{array}{l}\text { What I do to understand } \\
\text { what I hear: }\end{array}$ & & & & \\
\hline 10 & $\begin{array}{l}\text { I listen for the important } \\
\text { words. }\end{array}$ & $2(6.7)$ & $18(60.0)$ & $10(33.3)$ & 2.27 \\
\hline
\end{tabular}


INTERNATIONAL JOURNAL OF ACADEMIC RESEARCH IN PROGRESSIVE EDUCATION AND

DEVELOPMENT

Vol. 8, No. 3, 2019, E-ISSN: 2226-6348@ 2019 HRMARS

\begin{tabular}{|c|l|c|c|c|c|}
\hline 11 & $\begin{array}{l}\text { I listen for what seems } \\
\text { interesting. }\end{array}$ & $4(13.3)$ & $17(56.7)$ & $9(30.0)$ & 2.17 \\
\hline 12 & $\begin{array}{l}\text { I listen to words that are } \\
\text { repeated. }\end{array}$ & $5(16.7)$ & $5(16.7)$ & $20(66.7)$ & 2.50 \\
\hline $\begin{array}{c}\text { Section } \\
4\end{array}$ & $\begin{array}{l}\text { What I do if I still don't } \\
\text { understand what } \\
\text { someone says: }\end{array}$ & \multicolumn{4}{|l|}{} \\
\hline 13 & I ask the person to repeat. & $3(10.0)$ & $10(33.3)$ & $17(56.7)$ & 2.47 \\
\hline 14 & $\begin{array}{l}\text { I ask the person to slow } \\
\text { down. }\end{array}$ & $4(13.3)$ & $12(40.0)$ & $14(46.7)$ & 2.33 \\
\hline 15 & I ask a question. & $4(13.3)$ & $18(60.0)$ & $8(26.7)$ & 2.13 \\
\hline 16 & $\begin{array}{l}\text { I guess the meaning from } \\
\text { the person's tone (such as } \\
\text { angry or happy). }\end{array}$ & $3(10.0)$ & $12(40.0)$ & $15(50.0)$ & 2.40 \\
\hline 17 & $\begin{array}{l}\text { I guess the meaning from } \\
\text { how the person moves or } \\
\text { stands. }\end{array}$ & $9(30.0)$ & $14(46.7)$ & $7(23.3)$ & 1.93 \\
\hline 18 & $\begin{array}{l}\text { I guess the meaning from } \\
\text { what I heard before. }\end{array}$ & $2(6.7)$ & $16(53.3)$ & $12(40.0)$ & 2.33 \\
\hline
\end{tabular}

Section 4 in Part B of the questionnaire was meant to collect data on listening strategies that the respondents use if they still don't understand what someone says. As shown in Table 2, more than half of the total number of respondents (56.7\%) really used the strategy "I ask the person to repeat" if they still don't understand what someone says. This strategy denoted the highest mean score (2.47) among the other strategies in Section 4. These findings signified that the respondents preferred to ask the person to repeat what he or she has said in order for them to gain understanding. Repetition functions effectively in the teaching of listening to young learners because each repetition serves a different purpose. Listening at the first time helps the learners to get a general idea of the whole things the teacher is talking about. Findings in Section 4 also revealed that half of the total number of respondents $(50.0 \%)$ really used the strategy "I guess the meaning from the person's tone such as angry or happy" in order to gain understanding on what that person is saying. Although they share the similar mean score, the total number of respondents who thought the strategy "I guess the meaning from what I heard before" is somewhat like them and really describes them is higher (93.3\%) than the total number of respondents (86.7\%) for strategy "I ask the person to slow down". These findings illuminated that more respondents guess the meaning from what they have heard before if they still don't understand what someone is saying. The small number of respondents (13.3\%) who preferred to ask the person to slow down his speed when saying something is closely related to what have been stressed by Chitravelu, Sithamparam and Choon (2005) which is the speaker should not slow down their speed too much when talking because it does not help the learners to gain understanding. The higher number of respondents (30\%) who did not use strategy "I guess the meaning from how the person moves or stands" was probably due to the reason that the respondents were not observant kind of learners. 
INTERNATIONAL JOURNAL OF ACADEMIC RESEARCH IN PROGRESSIVE EDUCATION AND DEVELOPMENT

Vol. 8, No. 3, 2019, E-ISSN: 2226-6348 @ 2019 HRMARS

\section{RQ 2: To what extent do the ESL learners use speaking strategies in their language learning process?}

Section 1 of Part $C$ of the questionnaire as shown in Table 3 was meant to collect data on the learning strategies that the respondents used to practice speaking. Strategy "I practice using new grammar forms when I talk" denoted the highest mean score (1.87) with 21 respondents $(70.0 \%)$ used this strategy to practice speaking. It reflects that the respondents applied the grammar of the English language they have learned in speaking as a part of strategies to practice speaking. The awareness is placed not only to use the grammar correctly but also to enhance speaking skills. In a greater detail, this finding reflects a statement by Celce-Murcia and Larsen-Freeman (1999) which is "using language grammatically and being able to communicate are different but they are both important goals."

Surprisingly, there was none of the respondents who really used strategy "I say new expressions over to myself" to practice speaking. As shown in Table 3, there were 21 respondents (70.0\%) who did not say new expression over to themselves in order to practice speaking. This big number of respondents was probably because the respondents did not have the sufficient exposure to the English language due to social factors that they could use in speaking. As tabulated in Table 3 , half of the respondents $(50.0 \%)$ did not imitate the way the native speakers of the English language talk. This was probably due to the reason that the respondents preferred to make sounds of the English language until they can say them well and practice using new grammar form when they talk. Eventually, the ability to use these two strategies successfully give a great impact on the respondents' motivation to speak more and with confident.

Section 2 in Part $\mathrm{C}$ of the questionnaire placed an emphasis to collect data on strategies taken by the respondents in order to talk to others. As Table 3 shows, 29 respondents (96.7\%) preferred to start the conversation first. This great value illuminated that the respondents have good interpersonal skills. Meanwhile, strategy "I change the subject if I don't have the words I need" denoted the second highest mean score (2.20) after the earlier strategy (2.40) with 27 respondents $(70.0 \%)$ used it when talking with others. A big number of respondents (50\%) who did not plan what they are going to say was probably because they did not have the intention to speak grammatically correct but rather placed more focus to simply speak what came across their mind at that particular moment. 
INTERNATIONAL JOURNAL OF ACADEMIC RESEARCH IN PROGRESSIVE EDUCATION AND DEVELOPMENT

Vol. 8, No. 3, 2019, E-ISSN: 2226-6348 @ 2019 HRMARS

Table 3: Distribution, frequency and mean on speaking strategies use

\begin{tabular}{|c|c|c|c|c|c|}
\hline No. & Item & $\begin{array}{c}\text { The } \\
\text { statement } \\
\text { isn't like you } \\
\text { (\%) }\end{array}$ & $\begin{array}{l}\text { The } \\
\text { statement is } \\
\text { somewhat } \\
\text { like you (\%) }\end{array}$ & $\begin{array}{l}\text { The } \\
\text { statement } \\
\text { really } \\
\text { describes } \\
\text { you }(\%)\end{array}$ & Mean \\
\hline $\begin{array}{c}\text { Section } \\
1\end{array}$ & $\begin{array}{l}\text { What I do to practice } \\
\text { speaking: }\end{array}$ & & & & \\
\hline 1 & $\begin{array}{l}\text { I make the sounds of the } \\
\text { language until I can say } \\
\text { them well. }\end{array}$ & $11(36.7)$ & $15(50.0)$ & $4(13.3)$ & 1.77 \\
\hline 2 & $\begin{array}{l}\text { I imitate the way native } \\
\text { speakers talk. }\end{array}$ & $15(50.0)$ & $13(43.3)$ & $2(6.7)$ & 1.57 \\
\hline 3 & $\begin{array}{l}\text { I say new expressions over } \\
\text { to myself. }\end{array}$ & $21(70.0)$ & $9(30.0)$ & 0 & 1.30 \\
\hline 4 & $\begin{array}{l}\text { I practice using new } \\
\text { grammar forms when I } \\
\text { talk. }\end{array}$ & $9(30.0)$ & $16(53.3)$ & $5(16.7)$ & 1.87 \\
\hline $\begin{array}{c}\text { Section } \\
2\end{array}$ & $\begin{array}{l}\text { What I do to talk with } \\
\text { other people: }\end{array}$ & & & & \\
\hline 5 & I start conversations. & $1(3.3)$ & $16(53.3)$ & $13(43.3)$ & 2.40 \\
\hline 6 & $\begin{array}{l}\text { I change the subject if I } \\
\text { don't have the words I } \\
\text { need. }\end{array}$ & $3(10.0)$ & $18(60.0)$ & $9(30.0)$ & 2.20 \\
\hline 7 & $\begin{array}{l}\text { I plan what I am going to } \\
\text { say. }\end{array}$ & $15(50.0)$ & $10(33.3)$ & $5(16.7)$ & 1.67 \\
\hline 8 & $\begin{array}{l}\text { I ask the other person to } \\
\text { correct me when I talk. }\end{array}$ & $12(40.0)$ & $16(53.3)$ & $2(6.7)$ & 1.67 \\
\hline $\begin{array}{c}\text { Section } \\
3\end{array}$ & $\begin{array}{l}\text { When I can't think of a } \\
\text { word or phrase I want to } \\
\text { say: }\end{array}$ & & & & \\
\hline 9 & $\begin{array}{l}\text { I ask the person to help } \\
\text { me. }\end{array}$ & $2(6.7)$ & $16(53.3)$ & $12(40.0)$ & 2.33 \\
\hline 10 & $\begin{array}{l}\text { I try to say it a different } \\
\text { way. }\end{array}$ & $15(50.0)$ & $11(36.7)$ & $4(13.3)$ & 1.63 \\
\hline 11 & $\begin{array}{l}\text { I use words from my own } \\
\text { language. }\end{array}$ & $8(26.7)$ & $14(46.7)$ & $8(26.7)$ & 2.00 \\
\hline 12 & $\begin{array}{l}\text { I use words from my own } \\
\text { language but say them } \\
\text { with sounds from the new } \\
\text { language. }\end{array}$ & $9(30.0)$ & $16(53.3)$ & 5 (16.7) & 1.87 \\
\hline
\end{tabular}


INTERNATIONAL JOURNAL OF ACADEMIC RESEARCH IN PROGRESSIVE EDUCATION AND DEVELOPMENT

Vol. 8, No. 3, 2019, E-ISSN: 2226-6348 @ 2019 HRMARS

\begin{tabular}{|c|l|l|l|l|l|}
\hline 13 & $\begin{array}{l}\text { I move my hands and body } \\
\text { so the person will } \\
\text { understand me. }\end{array}$ & $17(56.7)$ & $10(33.3)$ & $3(10.0)$ & 1.53 \\
\hline
\end{tabular}

The findings tabulated in Table 3 (Section 3) illustrate the speaking strategies taken by the respondents when they could not think of a word or phrase they want to say. The findings indicated that 28 respondents (93.3\%) asked for help from others if they can't think of a word or phrase they want to say. This is a good strategy to take by the respondents rather than being quiet and stay wordless. Strategy "I use words from my own language" and "I use words from my own language but say them with sounds from the new language" came up with almost similar number of respondents, 22 (73.4\%) and 21 (70.0\%) respectively, who used these strategies when they are in a "wordless" situation. These findings really support the appropriateness of using mother tongue (L1) when the main subject of learning is to learn the English language. According to Harmer (2012), learners at the beginner levels tend to translate what is happening in their learning into their L1 as this is a natural process of learning a second or foreign language. On the other side of coin, more than half of the respondents $(56.7 \%)$ did not use body gestures to deliver their intentions if they can't think of what to say. Perhaps, these respondents are not kinesthetic kind of learners.

\section{RQ 3: To what extent do ESL learners use translation strategies in their language learning process?}

Part $D$ of the questionnaire was meant to collect data on the use of translation strategies among the respondents in this study. As tabulated in Table 4 (Section 1), all respondents (100\%) planned what they want to say or write in their language before translating it into English language. When translating, $96.6 \%$ of the respondents translated the language when reading in order to make sure they understand what they are reading whereas $90.0 \%$ of the respondent translated, while listening to someone, parts of what they say into their own language in order to help them remember the content. The high mean score for strategy "I translate when reading to make sure I understand" showed that the respondents really applied Grammar Translation Method (GTM) in their language learning. This statement supports Abdul and Hafiza (2016) who have highlighted that GTM reverses the language learning process as GTM starts with reading. By reading, the language learners actually can improve their accuracy in the use of English language (Hashim \& Yunus, 2018). 
INTERNATIONAL JOURNAL OF ACADEMIC RESEARCH IN PROGRESSIVE EDUCATION AND

DEVELOPMENT

Vol. 8, No. 3, 2019, E-ISSN: 2226-6348 @ 2019 HRMARS

Table 4: Distribution, frequency and mean on translation strategies use

\begin{tabular}{|c|c|c|c|c|c|}
\hline No. & Item & $\begin{array}{c}\text { The } \\
\text { statement } \\
\text { isn't like you } \\
\text { (\%) }\end{array}$ & $\begin{array}{c}\text { The } \\
\text { statement is } \\
\text { somewhat } \\
\text { like you (\%) }\end{array}$ & $\begin{array}{l}\text { The } \\
\text { statement } \\
\text { really } \\
\text { describes } \\
\text { you (\%) }\end{array}$ & Mean \\
\hline $\begin{array}{c}\text { Section } \\
1 \\
\end{array}$ & $\begin{array}{l}\text { What I do when I } \\
\text { translate: }\end{array}$ & & & & \\
\hline 1 & $\begin{array}{l}\text { I plan what I want to say or } \\
\text { write in my language and } \\
\text { then translate it into the } \\
\text { new language. }\end{array}$ & 0 & $13(43.3)$ & $17(56.7)$ & 2.57 \\
\hline 2 & $\begin{array}{l}\text { I translate when reading } \\
\text { to make sure I understand } \\
\text { it. }\end{array}$ & $1(3.3)$ & $13(43.3)$ & $16(53.3)$ & 2.50 \\
\hline 3 & $\begin{array}{l}\text { While I am listening to } \\
\text { someone. I translate parts } \\
\text { of what they say into my } \\
\text { own language to help } \\
\text { remember it. }\end{array}$ & $3(10.0)$ & $12(40.0)$ & $15(50.0)$ & 2.40 \\
\hline $\begin{array}{c}\text { Section } \\
2 \\
\end{array}$ & $\begin{array}{l}\text { What I do to think in the } \\
\text { new language: }\end{array}$ & & & & \\
\hline 5 & $\begin{array}{l}\text { I put my language out of } \\
\text { my mind. }\end{array}$ & $4(13.3)$ & $22(73.3)$ & $4(13.3)$ & 2.00 \\
\hline 6 & $\begin{array}{l}\text { I try to understand } \\
\text { without translating. }\end{array}$ & $3(10.0)$ & $22(73.3)$ & 5 (16.7) & 2.07 \\
\hline
\end{tabular}

Findings tabulated in Table 4 (Section 2) illustrate that almost all respondents put their language out of their mind (86.6\%) and tried to understand the language without translating it $(90.0 \%)$ when they think in the English language. These high percentages symbolize that the respondents did their very best not to translate the English language into their mother tongue (L1) when the situations require them to think in the English language. Instead, the respondents used English to the fullest.

\section{Conclusion}

The findings of study showed that all listening strategies are being used by the respondents in this study with at least 16 respondents (53.3\%) which is for strategy "I listen to the radio in the language". Apart from that, the findings also revealed that none of the respondents did not watch TV shows in the target language in order to listen more to that language. Overall, there were 15 out of 18 strategies denoted mean scores above 2.00 which means that majority of or almost all respondents used the listening strategies listed in the questionnaire. 
Based on the findings, it was found that only 4 out of 13 strategies being used by respondents in this study denoted mean scores higher than 2.00. This is because there was a big number of respondents who felt the speaking strategies are not really describing them or somewhat like them. These findings illuminated that majority of the respondents did not use some speaking strategies listed in the questionnaire when learning a new or target language.

Surprisingly, all translation strategies in Section 1 denoted mean scores higher than 2.00. This signifies that the respondents seemed to use translation strategies in their learning of new or target language. In GTM, mother tongue (L1) plays an important role in which the meaning of the target language is made clear by translating it into learners' L1 (Larsen-Freeman \& Anderson, 2011, as cited in Natsir \& Sanjaya, 2014). Apart from making the meaning clear for the learners, another benefit of using GTM is the vocabulary in the target language is memorized by the learners when being translated into their L1 (Natsir \& Sanjaya, 2014). To these benefits, Abdul and Hafiza (2016) came up with some disadvantages of GTM which are: 1) The use of target language is less in GTM class; 2 ) It is impossible to translate exactly from one language to another, and; 3) GTM reverses the learning process of a language. Therefore, language teachers need to be aware when planning to use GTM in their teaching of the target language. Limitation should be made in order to ensure adequate interaction between teacher and learners, not merely focusing on doing translation based on the reading texts. On the other side of coin, the mean scores denoted by the translation strategies in Section 2 revealed that almost all respondents preferred not to translate the new language to their first language. This is a healthy learning habit because it helps encouraging the respondents to think and allowing them to use the new language to the utmost.

This study implies that identifying learners' LLSs is one of the right approaches a language teacher should take because LLSs of a learner in one class may differ with his classmates' LLSs. Providing learners with unlimited learning experience is one kind of good actions a teacher should take and to achieve this mision, it is important for the teacher to ensure that his teaching meets the needs of learners' individual differences (Samat \& Hashim, 2019). According to Thirusanku and Yunus (2014), teachers must choose the right approach and teaching materials that are ideal for their learners. Adapting ICT in the teaching and learning could boost learners' LLSs and at the same time, as mentioned by Yunus and Suliman (2014) to increase the value of the teaching and learning process itself.

In conclusion, the findings of this study benefit the language teachers in primary schools in a way that they appear to be a good reference for them to be aware of their teaching approaches and to ensure their teaching approaches suit or fit learners' LLSs.

\section{Limitation and Study Forward}

In future researches, the researchers can come up with more LLSs for all four language skills including grammar and vocabulary in order to get sufficient data on LLSs among language learners. Since this research was focusing on pupils in a rural area primary school, there is a need that future researches can be conducted on pupils from urban primary schools so that the 
comparison can be made. It is also suggested that the future researchers to conduct studies on LLSs use among language learners in primary schools in three categories of rural area (Pedalaman 1, Pedalaman 2 and Pedalaman 3) where the exposure to the English language, and teaching and learning facilities are very limited.

\section{Acknowledgement}

The authors gratefully acknowledge the headmaster of this school for the cooperation and permission given to run this study in the school.

\section{References}

Abdul, B. K. \& Hafiza, S. M. (2016). The Effectiveness of Grammar Translation Method in Teaching and Learning of English Language at Intermediate Level. International Journal of Institutional \& Industrial Research, Vol. 1, Issue 1, pp.22-25.

Benson, P. and Voller, P. (eds.). (1997). Autonomy and independence in language learning. London: Longman.

Celce-Murcia, M., Brinton, D. M. \& Snow, M. A. (2014). Teaching English as a Second or Foreign Language, 4th ed. USA: National Geographic Learning.

Celce-Murcia, M. \& Larsen-Freeman, D. (1999). The Grammar Book: An ESL/EFL Teacher's Course, 2nd ed. USA: Heinle Cengage Learning.

Chitravelu, N., Sithamparam, S. \& Choon, T. S. (2005). ELT Methodology: Principles and Practice, 2nd ed. Selangor: Oxford Fajar.

Cohen, A. D. (1995). Second Language Learning and Use Strategies: Clarifying the Issues. Research Report. Revised Version.

Cohen, A. D. (2001). Preparing Teachers for Styles- and Strategies-Based Instruction. Paper presented at the International Conference on Language Teacher Education (2nd, Minneapolis, MN, May 17-19, 2001).

Cohen, A. D. (2002). Assessing and Enhancing Language Learners' Strategies. Higher Hebrew Education (HHE), Vol. 10.

Cohen, A. D. \& Weaver, S. J. (2005). Styles and Strategies-Based Instruction: A Teachers' Guide. CARLA Working Paper Series. A rewritten version of Paper \#7 (May 2005).

Gu, P. Y. (2005). Learning Strategies: Prototypical Core and Dimensions of Variation. Working Paper, No. 10.

Harmer, J. (2012). How to teach English. England: Pearson Longman.

Hashim, H. U. \& Yunus, M. M. (2018). English as a Second Language (ESL) Learning: Setting the Right Environment for Second Language Acquisition. Tadris: Jurnal Keguruan dan IImu Tarbiyah, Vol. 3, No. 2, pp. 207-215.

Kajan, D. D. \& Shah, P. M. (2019). Attitudes and Motivation of Young ESL Learners. International Journal of New Technology and Research (IJNTR), Vol. 5, Issue 1, pp. 22-27.

Macaro, E. (2004). Fourteen Features of a Language Learner Strategy. Working paper, No. 4.

Natsir, M. \& Sanjaya, D. (2014). Grammar Translation Method (GTM) versus Communicative Language Teaching (CLT): A review of literature. International Journal of Education \& Literacy Studies, Vol. 2, No. 1, pp. 58-62. 
INTERNATIONAL JOURNAL OF ACADEMIC RESEARCH IN PROGRESSIVE EDUCATION AND

DEVELOPMENT

Vol. 8, No. 3, 2019, E-ISSN: 2226-6348@ 2019 HRMARS

Oxford, R. L. (2003a). Language Learning Styles and Strategies: Concepts and Relationships. IRAL 41, pp. 271-278.

Oxford, R. L. (2003b). Language Learning Styles and Strategies: An Overview. GALA.

Oxford, R. \& Nyikos, M. (1989). Variables Affecting Choice of language Learning Strategies by University Students. The Modern Language Journal, Vol. 73, Issue 3.

Rahimi, M., Riazi, A. \& Saif, S. (2004). An investigation into the factors affecting the use of language learning strategies by Persian EFL learners.

Samat, N. A. A. \& Hashim, H. (2019). Language learning strategies employed by successful year 4 primary school pupils in Shah Alam. International Journal of Advance Research, Ideas and Innovations in Technology, Vol. 5, Issue 4, pp. 32-36.

Shin, J. K. \& Crandall, J. (2014). Teaching Young Learners English: From Theory to Practice. USA: National Geographic Learning.

Siti, H. S. \& Mohd, M. I. (2010). Analysis of errors in subject-verb agreement among Malaysian ESL learners. 3L The Southest Asian Journal of English Language Studies, Vol. 16, No. 1.

Surina, N. \& Kamaruzaman, J. (2009). A Study of Subject-Verb Agreement: From Novice Writers to Experts Writers. International Education Studies, Vol. 2, No. 3, pp. 190-194.

Surma, M. U. (2004). Autonomy in foreign language learning: An exploratory analysis of Japanese learners. Retrieved from: https://ro.ecu.edu.au/theses/785.

Tamada, Y. (1996). Japanese Learners' Language Learning Strategies: The Relationship between Learners' Personal Factors and Their Choices of Language Learning Strategies. Modern Language Journal, 80, pp. 120-131.

Thirusanku, J. \& Yunus, M. M. (2014). Status of English in Malaysia. Canadian Center of Science and Education, Vol. 10, No. 14, pp. 254-260.

Thompson, S. (2005). The "Good Language Learner". TEFL/ TESL Teaching. Module 2.

Yunus, M. M. \& Suliman, A. (2014). Information \& Communicative Technology (ICT) Tools in Teaching and Learning

Literature Component in Malaysian Secondary Schools. Canadian Center of Science and Education, Vol. 10, No. 7, pp. 136-152.

Zare, P. (2012). Language Learning Strategies Among EFL/ESL Learners: A Review of Literature. International Journal of Humanities and Social Science, Vol. 2 No. 5, pp. 162-169. 